INTERNATIONAL REAL ESTATE REVIEW

2010 Vol. 13 No. 2: pp. $218-237$

\title{
The Ongoing Financial Upheaval: Understanding the Sources and Way Out
}

\author{
Susan M. Wachter \\ Richard B. Worley Professor of Financial Management, The Wharton School, \\ University of Pennsylvania; Email: wachter@wharton.upenn.edu
}

The present period of financial instability is also likely to become known as the end of an era; an era of economic calm and policy consensus on ways to maintain market stability. After World War II, the federal government operated on the Keynesian principles that the right mix of spending, regulation, and interest rates could tame economic cycles and eliminate surges of unemployment. In this period, now known as the Great Moderation, we assumed that we knew how to prevent economic crises, such as the recurrence of the Great Depression. However, it is clear that those principles were erroneous as the economy has entered a lesser, but still severe downturn; the Great Recession. This paper looks at the sources of the ongoing economic crisis and points to the unique role in its origins of real estate asset bubbles and mispriced credit, not only in the origin of this crisis, but of many financial crises. An analysis of the data points to the role of mispriced mortgage backed securities (MBS) in the spread of aggressive mortgage products and the unwarranted price speculation that resulted in massive foreclosures. In turn, the paper addresses the source of mispriced risk in MBS as incomplete markets in real estate and non-tradability of MBS and related securities, which ultimately led to the collapse of financial system, threatening global economic health. The paper also suggests corrective measures that can and should be taken to assist the short and long term recovery. 


\section{Introduction}

The present period of financial instability is also likely to become known as the end of an era; an era of economic calm and policy consensus on ways to maintain market stability.

After a period of several decades known by macroeconomists as the Great Moderation, a period in which we assumed we knew how to prevent economic crises such as a recurrence of the Great Depression, we have experienced in the US and in many countries, the worst and longest recession in decades. I will address where we are today, the source of the crisis, and what can be done in the short and longer run to assist in the recovery.

\section{Where We Are Today}

In the last quarter of 2007, the US economy entered into the worst downturn since the Great Depression. With credit flows seized up, a self-reinforcing adverse cycle developed. The eroding financial system upended the economy, putting further pressure on the financial system. This crisis differs from previous postwar recessions in the US not only in its severity, but also in the collapse of the financial system itself. In response to this crisis, the Federal Reserve System (Fed) and the Treasury vastly expanded their roles. In addition, an unprecedentedly large fiscal stimulus package was implemented. However, more is needed for private credit flows to resume; confidence in the financial system must be restored. Restoring confidence requires an understanding of what went wrong as well as an effective response to reverse the decline.

Going forward, the economic outlook remains bleak for now. Although the spread between the three-month London interbank offered rate (LIBOR) and three-month T-bill rates, as shown in Figure 1, has recovered, credit markets remain badly shaken, with no private-label MBS issuance and little issuance of emerging market and private corporate debt. As Figure 1 also indicates, commodity and stock markets have been roiled, with US stock prices off about $30 \%$ to $40 \%$ from their peak in 2007. In the US, real GDP fell in Q4 of 2007, and again in Q3 and Q4 of 2008, and Q1 of 2009, at an annual rate of more than $6 \%$, although as of $\mathrm{Q} 2$, this decline has moderated to $1 \%$. Additionally, the economy has shed over seven million jobs so far on net (through July 2009), raising the unemployment rate by 4.6 percentage points to $9.5 \%$.

Reduced availability of credit and declining wealth have been the driving factors in the economic deterioration. Net worth has fallen by about $\$ 15$ trillion, more than $\$ 6$ trillion from a $30 \%$ decline in house prices, as shown in 
Figure 2, and $\$ 8$ trillion from the almost $50 \%$ decline in stock prices since their relative peaks.

Monetary and fiscal responses are also unprecedented. Monetary initiatives include a near zero federal funds target rate. The Fed has ramped up lending through credit facilities. Financial institutions can use securities as collateral to borrow from the Fed. Additionally, the Fed can now purchase almost all securities that it deems necessary. As a result of the Fed's actions, LIBOR and commercial paper rates have fallen and the volume of new issuance of commercial paper has sharply increased, and Fannie/Freddie mortgage rates have fallen to approximately 5\%. As of February 2009, Fannie/Freddie mortgage rates are near their lowest level in decades, but bank lending and private issuance of mortgage credit is limited to nearly nonexistent.

The goal of fiscal stimulus measures is to maximize the near-term boost to return to economic growth within two years. It has been estimated (Zandi, 2009) that without fiscal stimulus, real GDP would decline for seven quarters, falling by $2.5 \%$ in 2009 , and unemployment would exceed $10 \%$ with nearly five million jobs lost by mid-2010. Thus, it is hoped that the nearly $\$ 1$ trillion fiscal stimulus plan in 2009 will curtail real GDP and job losses. Even so, the stimulus would allow the economy to reach full employment only by the end of 2012.

Nonetheless, the nature of the crisis is such that these responses cannot return the economy to growth.

\section{Understanding the Sources of the Ongoing Financial Upheaval}

While these steps are necessary for recovery, they are not sufficient. The monetary authorities in the US have gone beyond traditional monetary policy to quantitative easing, since in the absence of continued direct funding to credit markets by the Fed, the Keynesian limits of pushing on a string have proven to be correct. Fiscal policy also has its limits due to long-term indebtedness concerns. The previous consensus on the difficulty of timing such stimulus so that it actually helps stem economic decline has been overcome both by the severity of the current event and the likelihood that the decline will be prolonged. 
Figure 1 Financial Series

DJIA and DJ-UBS Commodities Index (Left Axis) ${ }^{1}$; TED Spread (Right Axis)

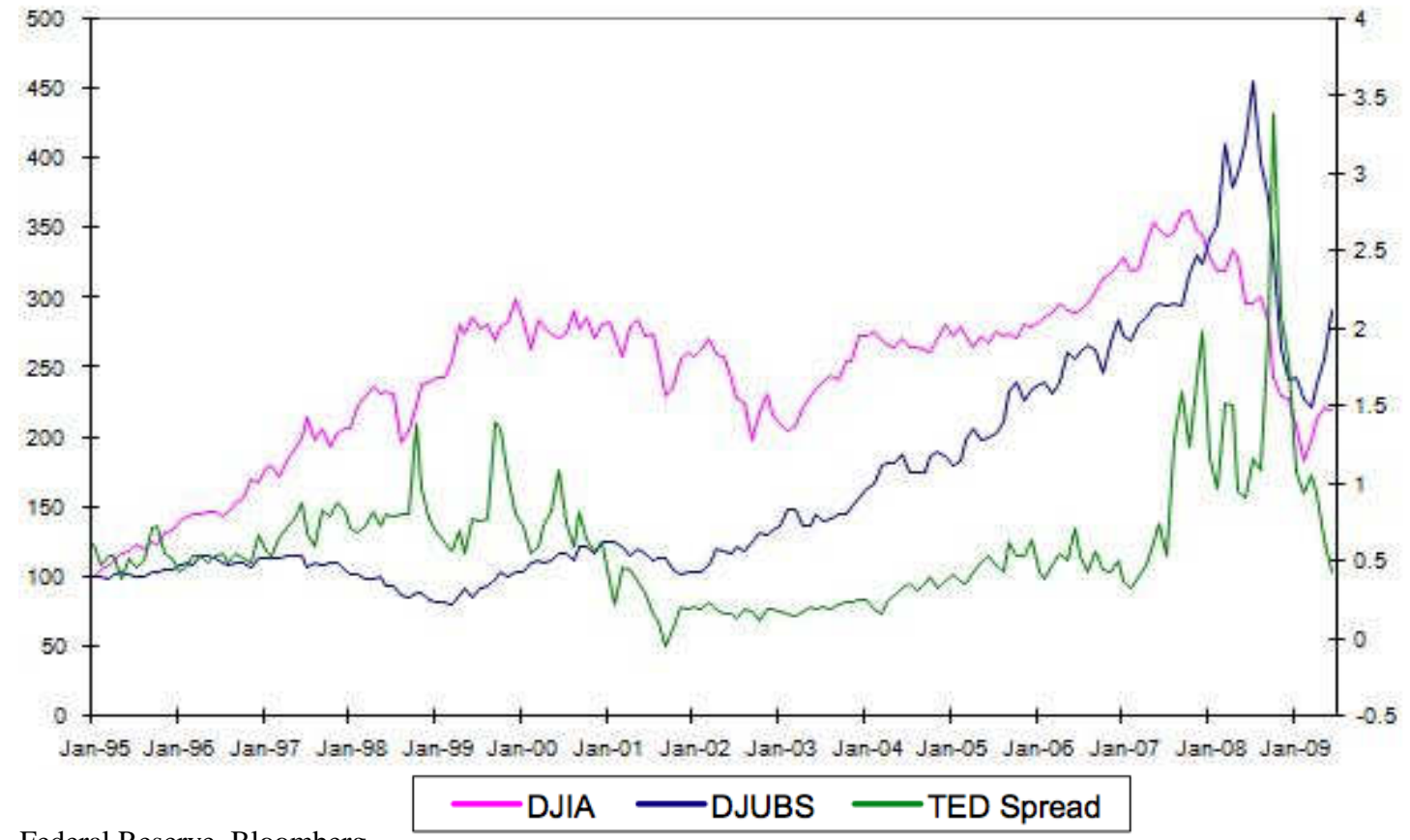

Sources: WSJ, BBA, Federal Reserve, Bloomberg

${ }^{1}$ Jan-95 $=100$ 
Figure 2 Case-Shiller ${ }^{2}$

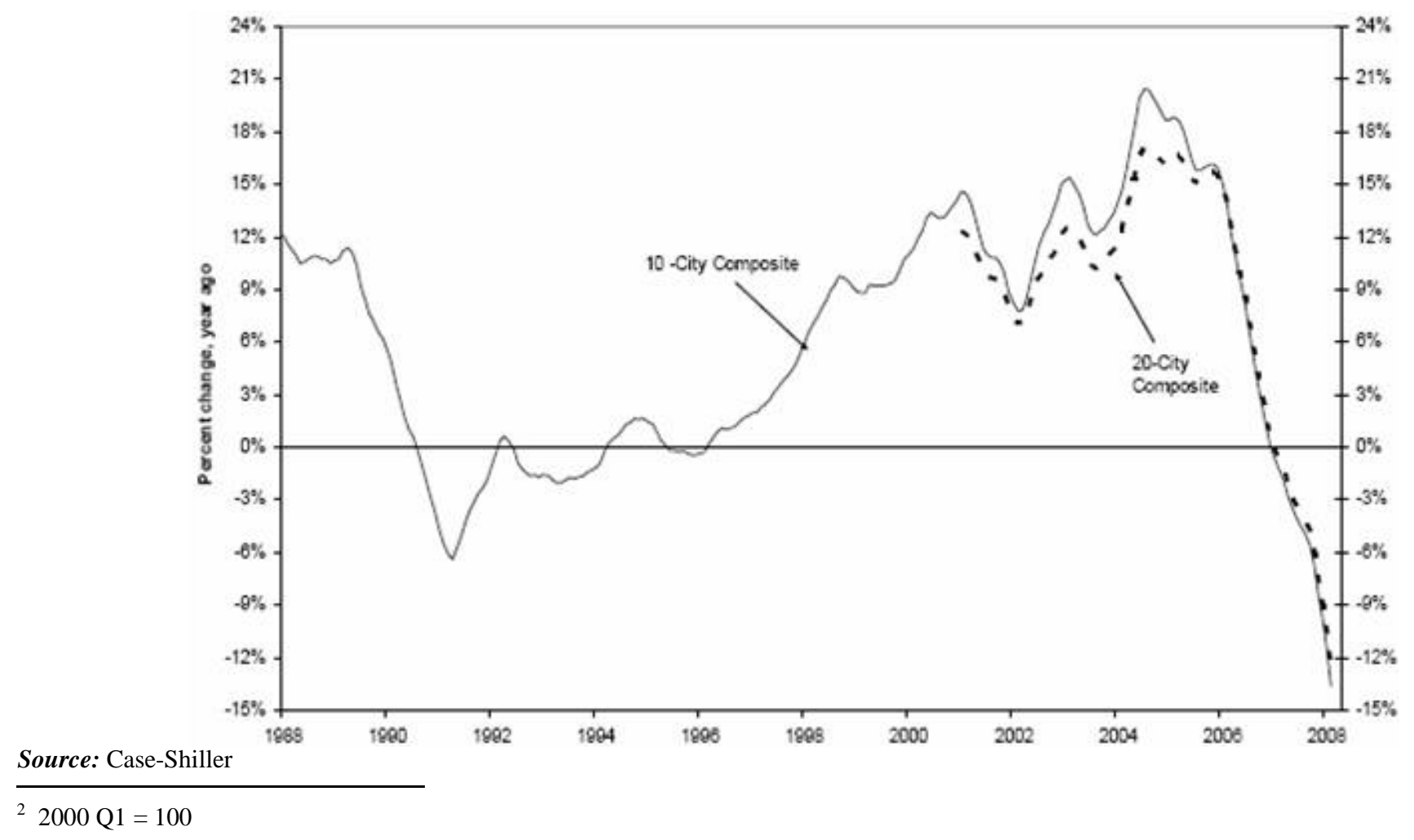

Source: Case-Shiller

${ }^{2} 2000 \mathrm{Q} 1=100$ 
Thus, fiscal and monetary stimulus will not suffice. The lesson from Japan is that for growth to reoccur, financial markets must function again. The balance sheets of banks have to be restructured, forcing the writing off of bad loans. The housing market needs to be dealt with so that nonperforming and underwater mortgages do not fuel an overshooting price decline, given the impediments to optimal workouts that currently exist in securitized pools.

Moreover, there needs to be confidence again that financial institutions are safe for investment and that there will be demand for their growth. Reinstilling confidence will require far greater certainty than that which exists today, in that the financial system will not expose investors to risks of unknown dimensions. For this, we will need to improve our understanding of the source of the current crisis and therefore, of the appropriate steps to prevent a recurrence.

While monetary policy reforms in many countries have helped to bring inflation under control, in past decades, asset price bubbles have worsened over time. With today's extreme debacle, there is only one in a series, which includes the Savings and Loan crisis in the US, the Asian Financial Crisis, and the earlier lost decade in Japan. ${ }^{3}$ Thus, we must improve our understanding of the source of this macro-instability.

Each of these episodes is preceded by an unsustainable build-up of debt. Also, in this crisis, household and financial debts as shares of GDP are pushed to unprecedented heights, as shown in Figure 3. Mortgage debt in particular increases along with the seemingly rising value of the underlying collateral, the housing asset. ${ }^{4}$ However, the question that is not addressed by this description of the crisis is why and how did leverage rise to unsustainable heights? At the time that these chronic imbalances were developing, the response was that asset prices correctly reflected low interest rates and thus debt-to-asset ratios were not out of balance. If assets were correctly priced, it was argued, high debt-to-income ratios would not produce a crisis since loans would be repayable through refinancing or sale of the property, if necessary.

\footnotetext{
${ }^{3}$ See Allen and Gale (2000), which documents previous episodes (in particular, Nordic countries and Japan in the late 1980s to early 1990s) in which rapid expansion of credit and asset price boom-and-bust cycles are intertwined.

${ }^{4}$ For a discussion of the links between housing wealth and economic activity, see Mishkin (2007). Also, for a general discussion on the development of the literature of macroeconomics and housing, see the review by Leung (2004) and the references therein. Mishkin links current and past financial crises to periods of rapid financial change, and to lending booms which "outstrip the available information resources in the financial system". Pavlov and Wachter (2009) points to the role of the procyclical decline in lending standards and the resulting rise in housing prices, which indeed, is in part due to inadequate information, as discussed further below.
} 
Figure 3 Chronic Imbalances
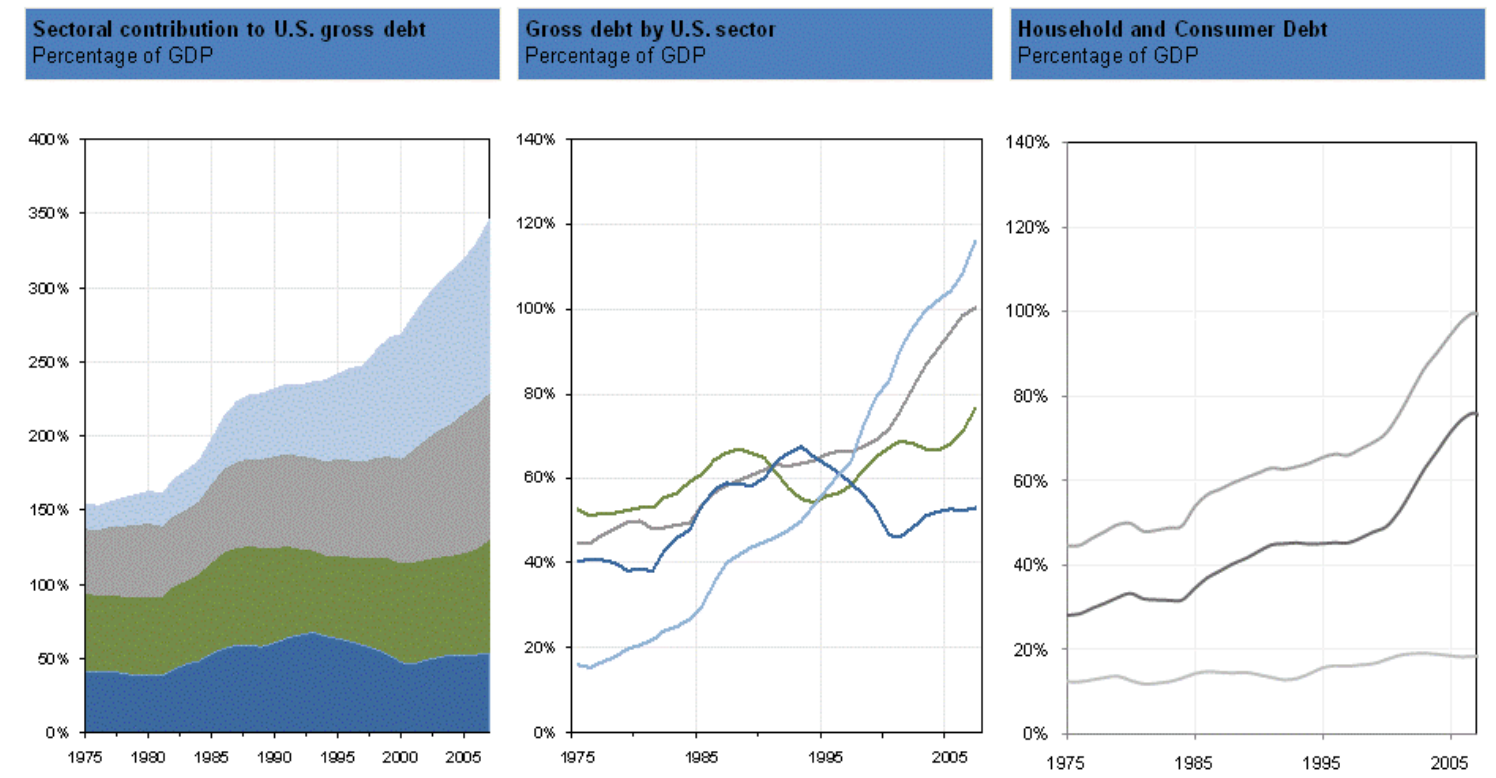

\begin{tabular}{|ll|}
\hline Financial Companies & Household \\
& Consumer Credit \\
& Homeninancial Companies Mortgage
\end{tabular}

Source: Federal Reserve Board Flow of Funds 
However, the problem was not simply low interest rate debt, rather, the problem was underpriced debt. As Pavlov and Wachter (2008) shows, inflated asset prices are the inevitable outcome of underpriced credit risk. If the default option in mortgage loans is underpriced, the inevitable outcome is an unsustainable rise in asset prices. When asset prices deflate, credit seizes up, and the high debt-to-income ratios become the immediate source of defaults. However, it is the asset price inflation and then deflation, and the mispriced credit that is responsible for defaults and the ever-widening crisis. Households, in the aftermath of the bubble, are then exposed both to a higher cost of credit and loans that they cannot repay due to the collapse in collateral values. The current crisis derives from a credit bubble which led to an asset bubble; in the absence of the credit bubble, the asset bubble would not have occurred. The credit and asset bubbles together are responsible for the severity of the global financial turmoil.

Although the crisis was preceded by a worldwide credit bubble, the US housing mortgage and housing markets are arguably at the center of the crisis. Abraham et al. provides evidence that the volatility adjusted run-up in US housing prices, particularly after 2003, exceeds price increases among US trading partners and that so far, the downturn in US housing prices has been the most severe (Figure 4, see Abraham, Pavlov and Wachter, 2008). The US run-up in housing prices was itself induced by a credit bubble of historically unprecedented dimensions. The introduction of subprime and other nontraditional mortgage (NTM) loans rapidly expanded after 2003, at terms that could not be repaid (Table 1). These aggressive loans allowed credit constraints to be overcome, expanding the demand for homes. The underpricing of the put option embedded in these loans also increased the price of the housing asset collateralized by the newly affordable, easy to get, and cheap loans.

The market share of these loans grew from under $15 \%$ to almost half of originations by 2006 (the sum of the market share of HELOCs, Alt-A, and subprime, as shown in Table 1). Within these loan types, the consolidated loan-to-value ratios (CLTVs) also increase, as shown in Table 2. Also, as shown in Table 2, as systemic risk increases with higher CLTVs (and with the growth in market share of these difficult-to-repay loans), the price of risk does not increase. In fact, the price of risk decreases, as shown by the decline in spreads. 
Figure 4 House Price Appreciation Controlled for Volatility

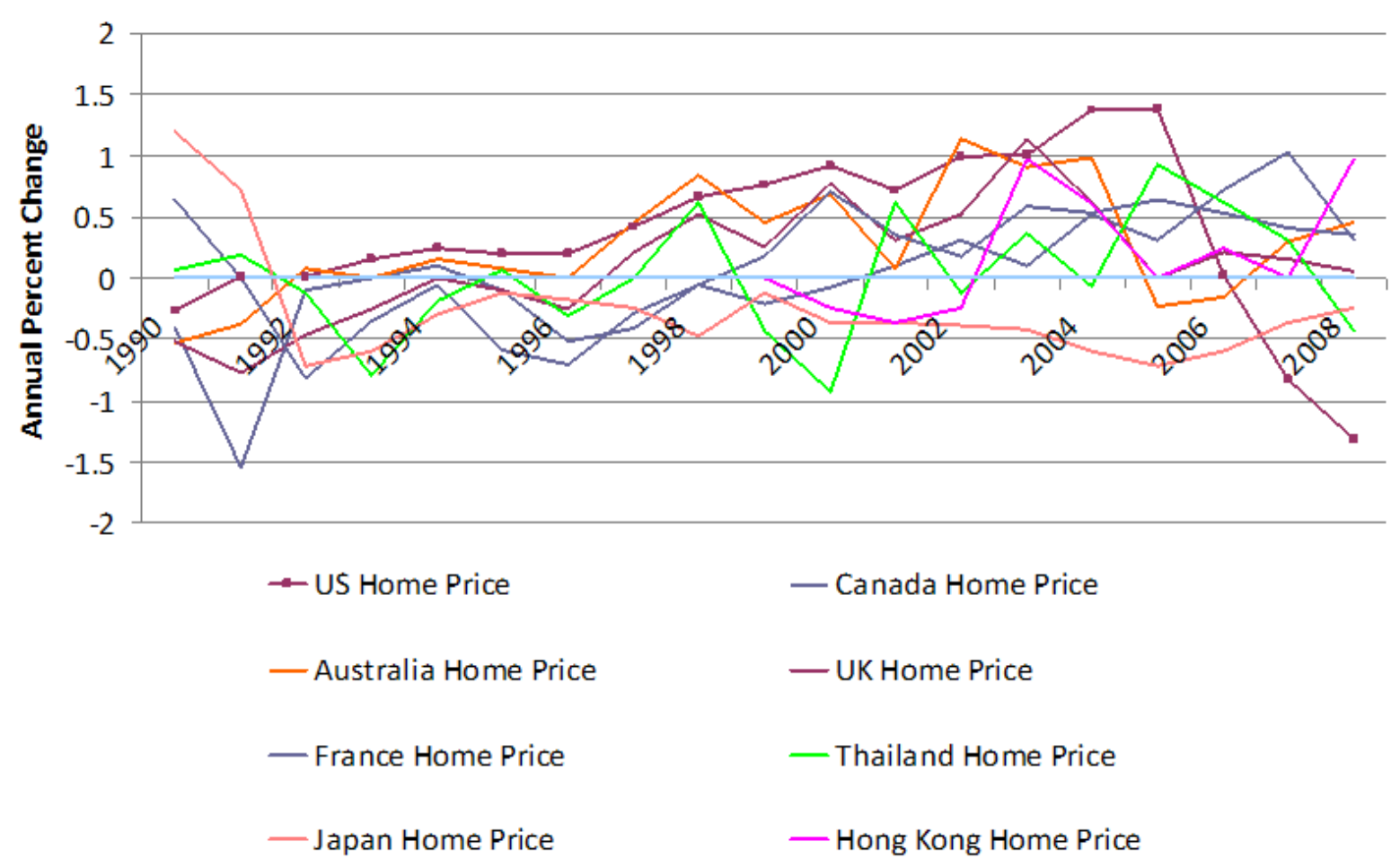

Source: Abraham et al 
Table 1 Mortgage Originations by Product

\begin{tabular}{|c|c|c|c|c|c|c|}
\hline & $\begin{array}{c}\text { FHA/VA } \\
\downarrow\end{array}$ & $\begin{array}{c}\text { Conv/Conf } \\
\downarrow\end{array}$ & $\begin{array}{c}\text { Jumbo } \\
\downarrow\end{array}$ & $\begin{array}{c}\text { Subprime } \\
\uparrow\end{array}$ & $\begin{array}{c}\text { Alt A } \\
\uparrow\end{array}$ & $\begin{array}{c}\text { HEL } \\
\uparrow\end{array}$ \\
\hline 2001 & $8 \%$ & $57 \%$ & $20 \%$ & $7 \%$ & $2 \%$ & $5 \%$ \\
\hline 2002 & $7 \%$ & $63 \%$ & $21 \%$ & $1 \%$ & $2 \%$ & $6 \%$ \\
\hline 2003 & $6 \%$ & $62 \%$ & $16 \%$ & $8 \%$ & $2 \%$ & $6 \%$ \\
\hline 2004 & $4 \%$ & $41 \%$ & $17 \%$ & $18 \%$ & $6 \%$ & $12 \%$ \\
\hline 2005 & $3 \%$ & $35 \%$ & $18 \%$ & $20 \%$ & $12 \%$ & $12 \%$ \\
\hline 2006 & $3 \%$ & $33 \%$ & $16 \%$ & $20 \%$ & $13 \%$ & $14 \%$ \\
\hline 2007 & $4 \%$ & $48 \%$ & $14 \%$ & $8 \%$ & $11 \%$ & $15 \%$ \\
\hline
\end{tabular}

Source: Inside Mortgage Finance 2008 Mortgage Market Statistical Annual

These loans are extended in states where mortgages were previously not affordable, thus expanding the market. Figures 5a, 5b, and 5c, respectively, show where housing is not affordable as of 2000, the concentration of subprime teaser rate adjustable rate mortgages (ARMs), and low documentation loans. When credit seized up in the spring of 2007, of course, it is these markets that were most vulnerable to declines. The same phenomenon of poorly underwritten, initially affordable, but then unaffordable loans, such as teaser rate loans whose required payments could double, occurred (although to a lesser extent) throughout the United States. However, it is in the high priced and difficult to develop, so-called sand states, that housing prices exploded with the wave of aggressive mortgage products and then imploded, as the tsunami receded (Figure 6). 
Table 2 Deterioration of Lending Standards

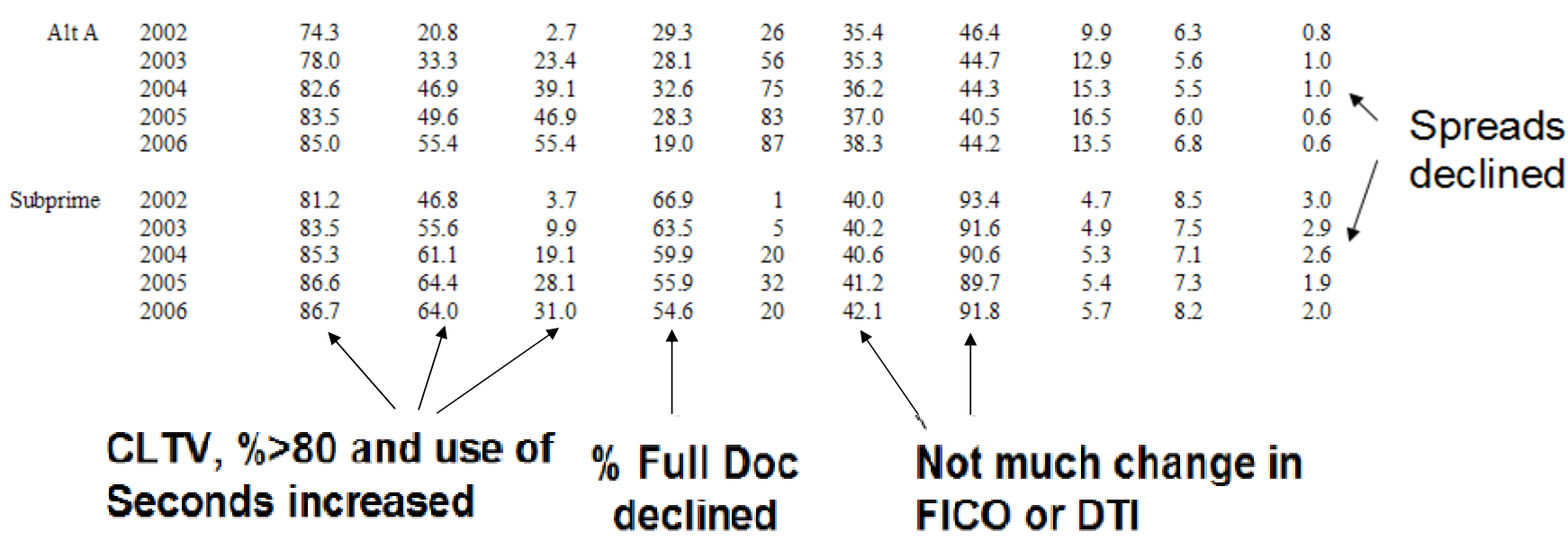

Source: Loan Performance data as of November 2006. UBS, April 16, 2007, Thomas Zimmerman, "How Did We Get Here and What Lies Ahead" 
Figure 5a 2006 Census Tract-\% Monthly Owner Costs with a Mortgage of 30 Percent or More

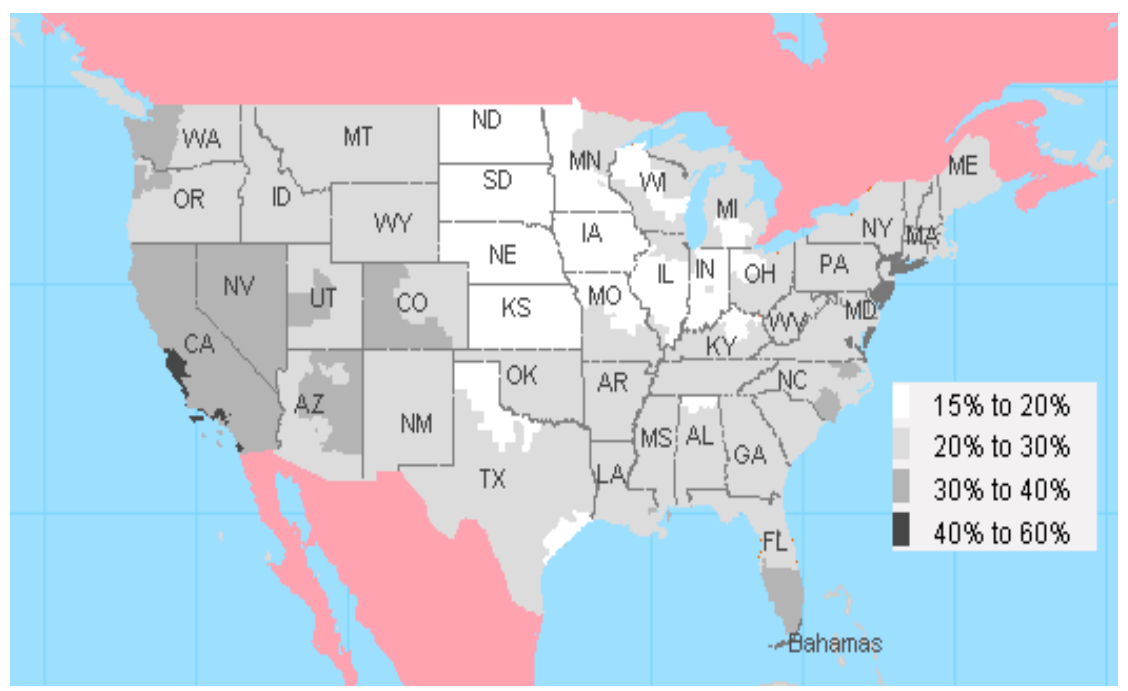

Source: SocialExplorer.com, 2000 U.S. Census

Figure 5b 2006 - Percentage of all Loans - Adjustable Rate

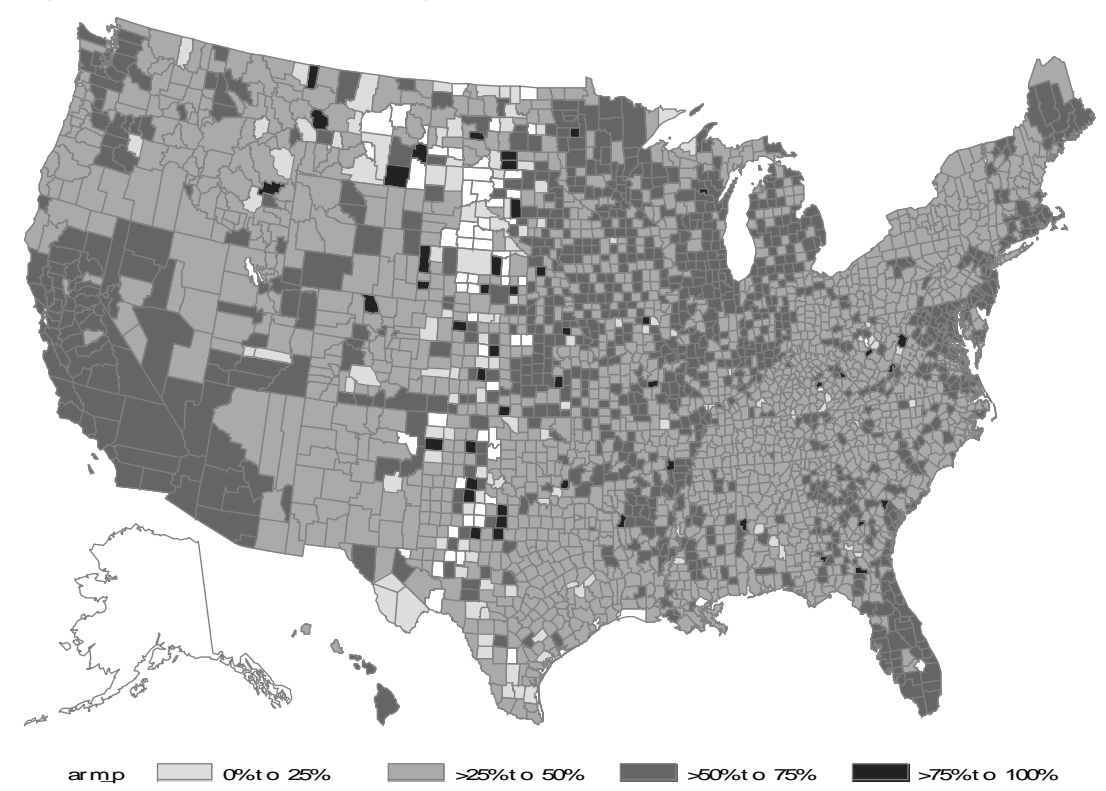

Source: Bostic et al. 
Figure 5c 2006 - Percent of all Loans - Low Documentation

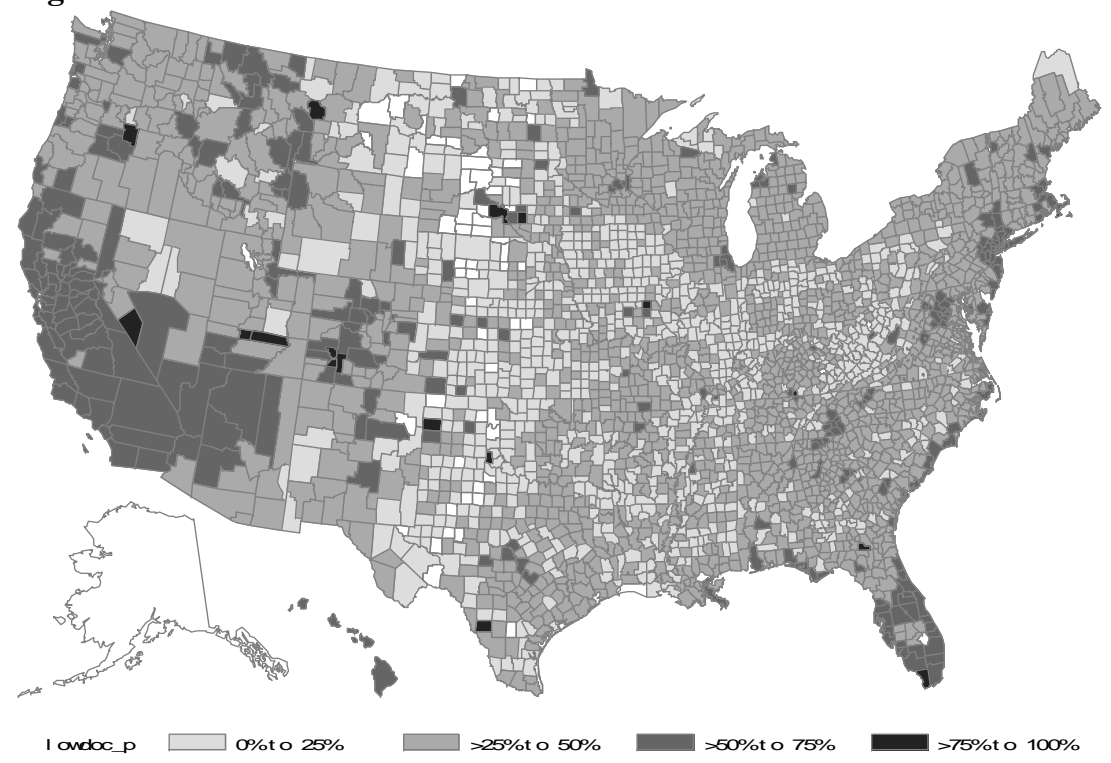

Source: Bostic et al.

Figure 6 A Housing Bubble in 2003, Especially in the "Sand States"

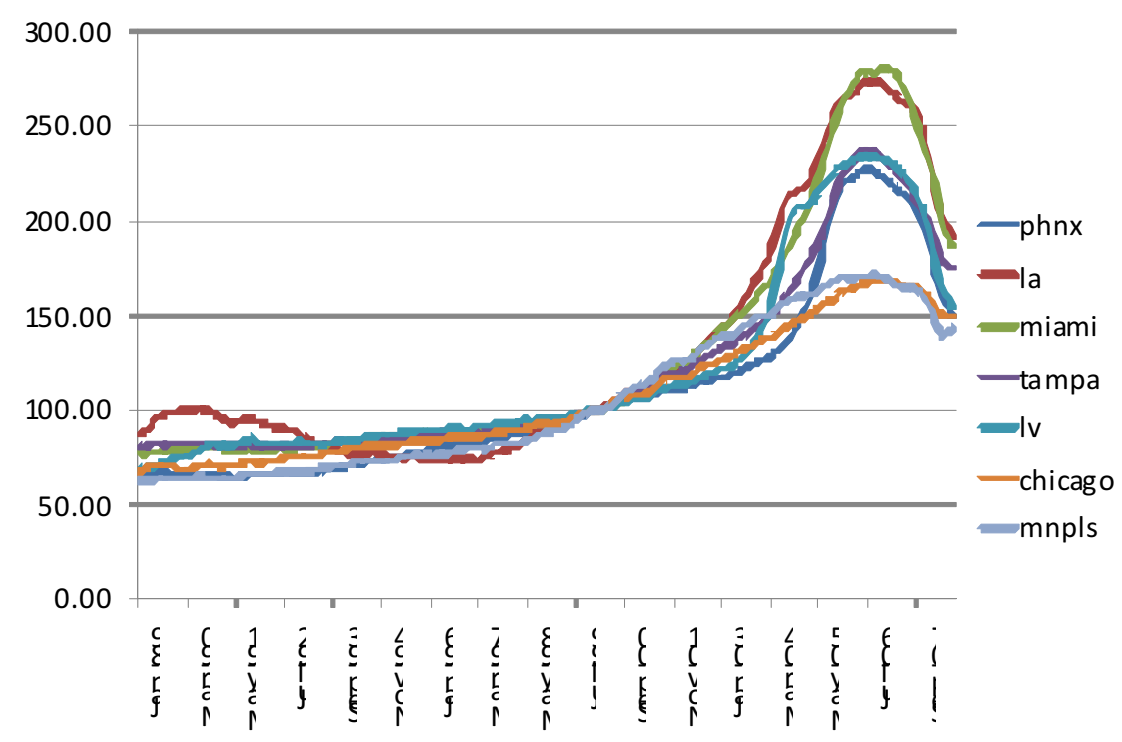

Source: Case-Shiller 
The problem of falling house prices, and mortgage defaults and foreclosures, is not confined to the subprime market. In fact, financial losses due to foreclosures in the far larger prime market may be greater in total dollar amount than those in the subprime market. The extension of credit increased the demand for all homes (and the overall indebtedness of the US households) and the subsequent withdrawal of credit reversed this demand. These mortgages were originally underwritten, generally using reasonable $80 \%$ CLTVs, but they are now also underwater. As home prices fall and unemployment rises, borrowers default on these loans as well. It was not foreseen that there would be difficulty in repaying these loans because CLTVs were in fact, reasonable, albeit at inflated market prices. With subprime and NTM credit no longer extended, price collapses were inevitable, impacting the default rate for prime loans as well.

Today's crisis in the US emerges from a shift in the source and pricing of funding for mortgage backed securities. While securitization has played a large role in the US, in the trading of MBS, investors have historically only been exposed to interest rate risk. Mortgage default risk was contained by underwriting, not priced and not borne by investors. With the growth of the private-label subprime market, this all changed.

In the process, fees drove the demand for securitization at every stage of the newly functionally differentiated production of mortgages. Banks received fees to originate-to-distribute, the secondary market received fees to bundle mortgages, and rating agencies received fees to rate the pools. At each stage, entities were able to book fees without exposure to long run-risks. Ultimately, investors purchased MBS. However, investors could also hedge their risk. With the purchase of newly available credit default swaps (CDS), their positions could be insured against possible loss. There was counterparty risk to be considered, but if this was evaluated, investors might have concluded that these instruments had to be backed up or the entire system would fail. The providers of the CDS perhaps would have been viewed as (and certainly in this event, they were viewed as) "too big to fail".

Of course, fees were collected for the rapidly growing provision of CDS as well.

The "too big to fail" entities behind CDS and the lack of observable market trading of CDS, or private label MBS more generally, allowed the expansion of these products without exposing them to better informed market observers who might have evaluated the pricing of these instruments and shorted them at their current prices. To reiterate (as shown in Table 2), as systemic risk increases, the price of risk does not. 


\section{Figure 7 How Did We Get Here?}

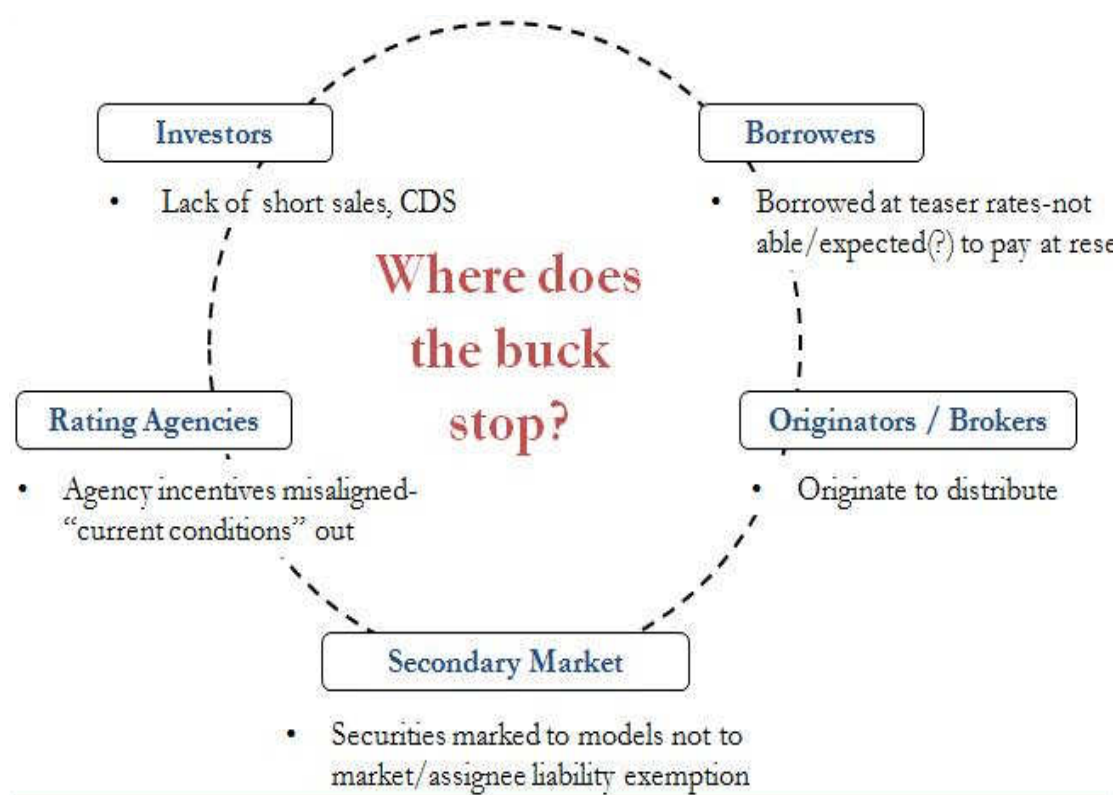

\section{A New Paradigm: The Pro-cyclical Production of Risk}

Lenders who are attempting to gain market share and increase their fees may do so by underpricing their competitors and expanding the universe of risky loans and/or by accepting additional risk. As they compete for product market share and expand their supply of risky loans, the average risk premium on these loans would increase if the premium correctly reflected the additional risk of the pool. However, as Table 2 indicates and as Pavlov and Wachter (2006) explain, in the production of nonrecourse loans collateralized by real estate, this does not occur. Rather, due to incomplete markets, the price of risk decreases, as lenders compete for market share. The result is the underpricing of risk and the overpricing of assets (Pavlov and Wachter, 2008).

Due to heterogeneity and illiquid markets, mortgage backed securities and related derivatives trade infrequently, thus short selling these overpriced assets is infeasible. Mortgage backed securities are marked to model, not to market, and could not be traded to drive prices to fundamental levels through short-selling pressure.

The result of this underpriced risk and the lack of short selling is that asset price increases could persist and increase with further easing of credit. With artificially inflated asset prices, the balance sheets of financial institutions are 
also artificially inflated (Pavlov and Wachter, 2009a and 2009b). ${ }^{5}$ Thus, the higher prices of real estate assets inaccurately reflect the risk of real estate loans on the balance sheets of banks. As Herring and Wachter (1999) shows, real estate booms and banking busts tend to go together. In fact, the current financial upheaval is only the most recent in a series of financial crises in which property-based asset booms are accompanied by financial system failure. In the absence of arbitrage, asset bubbles occur, and the result is increased systemic risk as liquidity providers who hold these assets are decapitalized pro-cyclically.

\section{Table 3 The Pro-cyclical Production of Risk as Lending Increases}

Lenders accept additional risk for increased initial fees and market share and rates decline

- Efficient Outcome: Risk premia increase and asset prices decrease

- Inefficient Outcome: Risk premia decrease and asset prices increase due to incomplete markets in real estate

Coexistence of real estate booms and banking busts

- Increased perceived bank capital

- Evidenced by the recent crisis in which property based asset booms accompanied increases in financial and systemic risk

- Others: S\&L Crisis, Asian Financial Crisis, Japan's Lost Decade

Source: Pavlov and Wachter (2009b), Herring and Wachter

Would derivative trading in these markets have made a difference and contained the asset bubble? In the US, derivative markets (the $\mathrm{ABX}$ ) were introduced in 2006, which may have helped to contain the risk, although from the timing it is difficult to tell. It was not until March 2007 that the ABX signaled mispricing, and even at that point, aggressively priced subprime lending continued. Derivative trading in the UK, which had predicted a collapse in property markets prior to 2007 , did not stop credit expansion in an overextended market. Short selling is not sufficient in the presence of too-bigto-fail buyers.

\footnotetext{
${ }^{5}$ Thus the cycle mechanism operates through a financial system. Iacoviello (2005) links the constraint and nominal debt contract features of mortgage contracts to a wealth effect that dampens the business cycle.In contrast, Pavlov and Wachter (2009 a, $2009 \mathrm{~b}$ ) identify this pro-cyclical impact through the overcoming of the constraint and increased value of the put option with nonrecourse debt. See also Kyotaki and Moore (1997) who develop a credit cycle model of non-recourse debt to show the dynamic interaction between credit limits and asset prices, and persistent fluctuations in output and asset prices.
} 


\section{How Is This To Be Avoided?}

The lesson appears to be that as long as credit is being extended by entities with a short-run view to maximizing profits, and the power and financial incentive to do so, even if mispriced for ultimate risks, they will do so. This clearly includes "too big to fail" entities which use demand deposit insured funds or other "protected" borrowing sources to garner short-term profits and market share (McCoy et al., 2008). The credit induced asset bubble covers up the deterioration in credit standards with the result of an extended period in which the bubble continues to form and credit risk underpricing becomes more severe.

The symptom that identifies a credit induced asset bubble is the correlated easing of credit observed with non-fundamentally derived asset price inflation. Regulation and prudential supervision can limit bubbles in property markets that are the result of pro-cyclical deterioration in underwriting standards. In analyzing the Asian Financial Crisis, we present evidence that countries experienced a more moderate property crash where underpricing of credit was kept under control by prudential supervision of the regulatory authorities (Koh et al. 2004). In particular, this has been accomplished by the Monetary Authority of Hong Kong, as we have shown.

In order to take action to avoid property market bubbles induced by procyclical erosion in credit standards, it is necessary to observe that this is occurring. Without market indicators and understanding of this phenomenon, regulators will not be prompted to take appropriate prudential action. There is now an emerging consensus that balance sheets of banks and large non-bank entities must be kept well capitalized. Nevertheless, how is it to be known that capital, which includes value derived from property, is sufficient?

In much cited work, Bernanke and Gertler $(1999,2002)$ discount the utility of inflation targeting to contain asset bubbles. However, Cecchetti et al. (2000) show the utility of containing asset bubbles, if they entail liquidity crises. It is an open question as to the instrument that should be used to contain a credit induced asset bubble. ${ }^{6}$ The mechanism implemented must address the question of the potential sufficiency of the underlying value of the collateral, since this is the direct risk induced by the artificially inflated asset prices. When there is a heightened risk that an underpriced credit induced asset bubble is occurring, consideration should be given to instituting "speed bumps" that would require higher minimum capital reserves. However, in order to observe the correlation of these risks, we first need to observe,

\footnotetext{
${ }^{6}$ The focus has been on the use of interest rates, although the literature suggests moves in contrary directions, see Cecchetti et al. (2000) and Faia and Monacelli (2007). It is an open question which instrument should be used but the central bank's ability to use interest rates as a tool to contain inflation should not be compromised.
} 
measure, and track asset pricing, and also the pricing and terms of financing. To quote Chairman Bernanke, "The events of the past year or two have highlighted regulatory gaps and deficiencies that we must address... As we recover from the current crisis, it will be important to address these issues as soon as possible, to develop a regulatory structure that will better respond to future economic challenges" (Wall Street Journal, October 14, 2008). There is much work to be done.

\section{References}

Abraham, J. M., Pavlov, A., and S. Wachter. (2008). Explaining the United States' Uniquely Bad Housing Market, Wharton Real Estate Review, 12, 24-41.

Allen, F. and D. Gale. (2000). Bubbles and Crises, Economic Journal, 110, 460, 236-255.

Bernanke, B. and M. Gertler. (1999). Monetary Policy and Asset Price Volatility, Federal Reserve Bank of Kansas City Economic Review, 4, 17-53.

Bernanke, B. and M. Gertler. (2002). Should Central Banks Respond to Movements in Asset Prices?, AER Papers and Proceedings.

Bostic, R., Chomsisengphet, S., Engel, K. C., McCoy, P. A., PenningtonCross, A. and S. M. Wachter. (2009). Mortgage Product Substitution and State Anti-Predatory Lending Laws: Better Loans and Better Borrowers?, Working Paper.

Bostic, R., Engel, K. C., McCoy, P. A., Pennington-Cross, A. and S. M. Wachter. (2000). State and Local Anti-Predatory Lending Laws: The Effect of Legal Enforcement Mechanisms, Journal of Economics and Business, 60, 47-66.

Cecchetti, S., Genberg, H., Lipsky, J., and Wadhwani. S. (2000). Asset Prices and Central Bank Policy, London: International Center for Monetary and Banking Studies.

Faia, E. and Monacelli, T. (2007). Optimal Interest Rate Rules, Asset Prices and Credit Frictions, Journal of Economic Dynamics and Control, 31, 10, 3228-3254. 
Green, R. K. and S. M. Wachter. (2007). The Housing Finance Revolution, $31^{\text {st }}$ Economic Policy Symposium: Housing, Housing Finance, \& Monetary Policy, Jackson Hole, Wyoming, Federal Bank of Kansas City.

Green, R. K., Mariano, R., Pavlov A., and S. M. Wachter. (2007). Misaligned Incentives and Mortgage Lending in Asia, National Bureau of Economic Research Working Paper.

Green, R. K. and S. M. Wachter. (2005). The American Mortgage in Historical and International Context, Journal of Economic Perspectives, 19, 4, 93-114.

Herring, R. and S. M. Wachter. (1999). Real Estate Booms and Banking Busts: An International Perspective, Washington, D.C.: Group of Thirty.

Iacoviello, M. (2005). House Prices, Borrowing Constraints and Monetary Policy in the Business Cycle, American Economic Review, 95, 3, 739-764.

Kiyotaki, N. and J. Moore. (1997). Credit Cycles, Journal of Political Economy, 105, 2, 211-248.

Koh, W. T. H., Mariano, R. S., Pavlov, A. D., and S. M. Wachter. (2004). Bank Lending and Real Estate in Asia: Market Optimism and Asset Bubbles, Journal of Asian Economics, 15, 6, 1103-1118.

Leung, C. (2004). Macroeconomics and Housing: A Review of the Literature, Journal of Housing Economics, 13, 249-267.

McCoy, P. A., Pavlov, A. D., and S. M. Wachter. (2009). Systemic Risk Through Securitization: The Result of Deregulation and Regulatory Failure, Connecticut Law Review, 41, 493-541.

Mishkin, F. S. (2007). Housing and the Monetary Transmission Mechanism, NBER Working Paper Series.

Pavlov, A. D., Poznar, Z., and S. M. Wachter. (2008). Subprime Lending and Real Estate Markets in: Mortgage and Real Estate Finance, S. Perrucci (ed.). London: Risk Books, 325-340.

Pavlov, A. D. and S. M. Wachter. (2006). The Inevitability of Market-Wide Underpricing of Mortgage Default Risk, Real Estate Economics, 34, 479-496.

Pavlov, A. D. and S. M. Wachter. (2009a). Mortgage Put Options and Real Estate Markets, Journal of Real Estate Finance and Economics, 38, 89-103. 
Pavlov, A. D. and S. M. Wachter. (2009b). Subprime Lending and House Price Volatility, Working Paper.

Pavlov, A. D. and S. M. Wachter. (2009c). Systemic Risk and Market Institutions, Yale Journal on Regulation, Forthcoming.

Zandi, M. (2009). The Economic Impact of the American Recovery and Reinvestment Act, Moody's Economy.com.

(www.economy.com/markzandi/documents/Economic_Stimulus_House_Plan _012109.pdf). 